\title{
Case Report and Review of Eccrine Porocarcinoma in Skin of Color
}

\author{
Sadhana Sruveera Sathi, MS ${ }^{1}$, Elizabeth M. Dugan, MD, ${ }^{2}$ Maral Kibarian Skelsey, $\mathrm{MD}^{2}$ \\ ${ }^{1}$ Georgetown University School of Medicine, Washington, DC \\ ${ }^{2}$ Dermatologic Surgery Center of Washington, DC
}

\section{ABSTRACT}

Skin cancers are often misdiagnosed or diagnosed late in skin of color (Fitzpatrick types 4-6) resulting in increased morbidity and mortality. Rare skin cancers such as Eccrine Porocarcinoma (EPC), which accounts for $0.005 \%$ to $0.01 \%$ of all epidermal skin neoplasms, are even less likely to be accurately diagnosed in skin of color. Eccrine Porocarcinoma is often misdiagnosed as Squamous cell carcinoma (SCC), Basal Cell Carcinoma (BCC), melanoma, and seborrheic keratosis. The paucity of case reports of EPC in skin of color adds to the challenge of achieving accurate, timely diagnosis and treatment in this patient population. The purpose of this research is to review case reports of EPC documented in skin of color, highlighting salient clinical and histopathological characteristics of EPC, and to describe an additional case of EPC in skin of color that was initially misdiagnosed as seborrheic keratosis. Our search combined "eccrine porocarcinoma" and one of the following terms: "ethnic skin", "skin of color", "black", "dark skin", "African American", "Indian", "Native American", "Asian", "Hispanic", "Indigenous Peoples", "Middle Eastern" —as these tend to correspond with Fitzpatrick IV - VI types. Google scholar, PubMed, and Ovid MedLine Databases were used to search for articles. Case reports ranging from 1994 to present day were included in analysis.

\section{INTRODUCTION}

Skin cancers are often misdiagnosed or diagnosed late in skin of color (Fitzpatrick types 4-6) resulting in increased morbidity and mortality. Rare skin cancers such as Eccrine Porocarcinoma (EPC), which accounts for $0.005 \%$ to $0.01 \%$ of all epidermal skin neoplasms, are even less likely to be accurately diagnosed in skin of color. ${ }^{1}$ Misdiagnosis of EPC is common due to its resemblance to skin cancers such as SCC, BCC, melanoma, and presence of atypical cell types in histology. The lack of case reports of EPC in skin of color adds to the challenge of achieving an accurate and timely detection, diagnosis, and treatment in this patient population. The purpose of this research is to review case reports of EPC documented in skin of color, identify, and highlight salient clinical and histopathological characteristics of EPC in this patient population, and to describe an additional case of EPC in skin of color encountered in the clinic that was initially misdiagnosed as seborrheic keratosis.

\section{METHODS}

Our search combined "eccrine porocarcinoma" and one of the following terms: "ethnic skin", "skin of color", "black", "dark skin", "African American", "Indian", "Native American", "Asian", "Hispanic", March 2022 Volume 6 Issue 2 
"Indigenous Peoples", "Middle Eastern" -as these tend to correspond with Fitzpatrick IV - VI types. Google scholar, PubMed, and Ovid MedLine Databases were used to search for articles. Case reports ranging from 1994 to present day were included in analysis.

\section{CASE REPORT}

We present a case of an 82-year-old African American male (Fitzpatrick type 5/6), who was referred to the Dermatologic Surgery Center of Washington for an enlarging nodule on the right lateral malleolus. Initial biopsy by the referring physician 3 years prior demonstrated a seborrheic keratosis. Past medical history was significant for bilateral kidney transplant 7 years prior secondary to diabetic nephropathy.

The cutaneous exam showed a $2 \times 1.5 \mathrm{~cm}$ skin colored nodule with an erosive center on the right lateral malleolus (Figure 1).

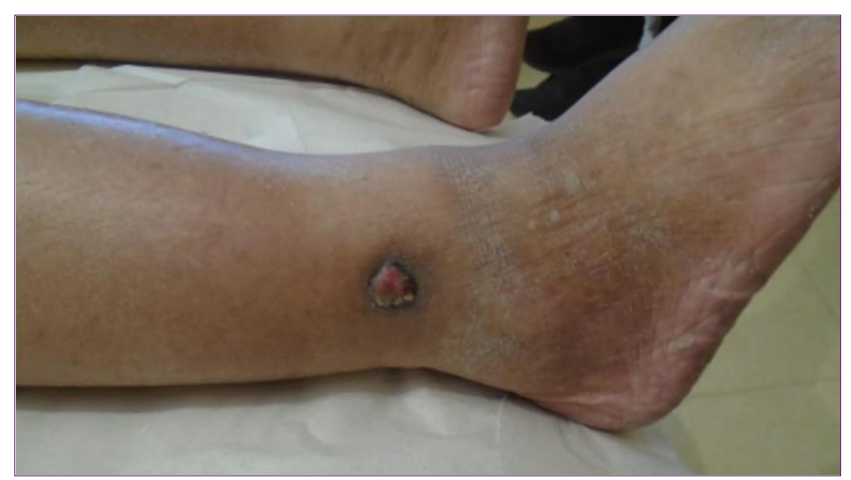

Figure 1.

There was palpable inguinal lymphadenopathy but no cervical or axillary lymphadenopathy. Pathology findings showed an exophytic lesion of skin with a well demarcated proliferation of atypical epithelial cells that emanated from the epidermis and extended into the dermis. This proliferation contained small duct-like structures within and resembled anastomosing wide bands of cells. Many epithelial cells were found to have enlarged, hyperchromatic, and pleomorphic nuclei surrounded by eosinophilic cytoplasm. There are also atypical mitoses present and the neoplasm was surrounded by a prominent fibrovascular stroma (Figure 2).

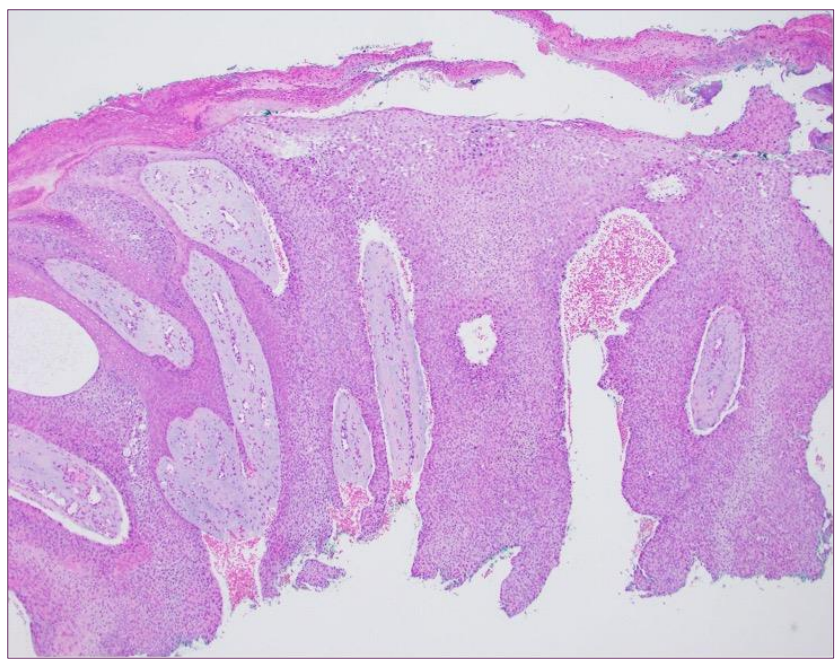

Figure 2.

Mohs surgery was performed with the tumor being cleared after 2 stages and there is no evidence of recurrence or metastatic disease at 10 months follow-up.

\section{RESULTS}

Robson et al. conducted one of the largest reviews of EPC, which contains 69 cases and offers a comparator dataset to this review. ${ }^{1}$ Our review identified 12 additional cases of EPC described in patients of color whose ethnic origins included Japanese, Indian, Hispanic, and African American, making $n=13$ with the present case. The cases as presented in Table 1, showed a slightly higher predilection in females $(n=8)$ compared to 
Table 1.

\begin{tabular}{|c|c|c|c|c|c|c|c|c|}
\hline Paper Author & $\begin{array}{l}\text { Gender, } \\
\text { Ethnicity }\end{array}$ & Age & $\begin{array}{l}\text { Location of } \\
\text { lesion }\end{array}$ & $\begin{array}{l}\text { Gross } \\
\text { findings/Misdiagnosis if } \\
\text { present }\end{array}$ & $\begin{array}{l}\text { Years of } \\
\text { lesion } \\
\text { growth }\end{array}$ & $\begin{array}{l}\text { Lymph Node } \\
\text { Enlargement present? }\end{array}$ & Microscopic Features & Treatment \\
\hline $\begin{array}{l}\text { 1) Cowden et } \\
\text { al. }{ }^{3}\end{array}$ & $\begin{array}{l}\text { Male, } \\
\text { African } \\
\text { American }\end{array}$ & 56 & $\begin{array}{l}\text { Right Upper } \\
\text { Back }\end{array}$ & $\begin{array}{l}4 \times 5 \mathrm{~cm} \text { polypoid mass with } \\
\text { occasional bleeding }\end{array}$ & $1-2$ years & Not reported & $\begin{array}{l}\text { Anastomosing cords of } \\
\text { bland epithelial cells of } \\
\text { poroma type penetrating } \\
\text { the dermis; sections with } \\
\text { cytological atypia, } \\
\text { squamous } \\
\text { differentiation, clear cell } \\
\text { change and abnormal } \\
\text { mitotic activity; } \\
\text { associated with a } \\
\text { fibrovascular stroma. 0-6 } \\
\text { mitoses per hpf }\end{array}$ & $\begin{array}{l}\text { Mohs micrographic } \\
\text { surgery, } 3 \text { stages. Did } \\
\text { not show for follow-up } \\
\text { appointments }\end{array}$ \\
\hline $\begin{array}{l}\text { 2) Cowden et } \\
\text { al. }^{3}\end{array}$ & $\begin{array}{l}\text { Female, } \\
\text { African } \\
\text { American }\end{array}$ & 71 & Right Heel & $\begin{array}{l}\text { Large verrucous plaque } \\
\text { containing a moist red nodule }\end{array}$ & $>1$ year & Not reported & $\begin{array}{l}\text { Proliferation of atypical } \\
\text { epithelial cells with } \\
\text { ductal differentiation } \\
\text { emanating from the } \\
\text { epidermis and extending } \\
\text { into the dermis. } 9 \text { to } 35 \\
\text { mitoses per hpf. } 2.75 \\
\text { mm depth }\end{array}$ & $\begin{array}{l}\text { Mohs micrographic } \\
\text { surgery with clear } \\
\text { margins }\end{array}$ \\
\hline $\begin{array}{l}\text { 3) Girishkumar } \\
\text { et al. }{ }^{4}\end{array}$ & $\begin{array}{l}\text { Female, } \\
\text { African } \\
\text { American }\end{array}$ & 40 & $\begin{array}{l}\text { Anterior } \\
\text { aspect of } \\
\text { left leg }\end{array}$ & $\begin{array}{l}2.5 \times 2 \mathrm{~cm} \text {, indurated, firm } \\
\text { pigmented lesion. Superficial } \\
\text { ulceration }\end{array}$ & $>20$ years & No & $\begin{array}{l}\text { Extended into dermis, } \\
\text { pattern of broad bands } \\
\text { and well-defined satellite } \\
\text { islands. Islands of tumor } \\
\text { cells infiltrated } \\
\text { subcutaneous adipose } \\
\text { tissue. Cells were } \\
\text { cuboidal, uniform. } \\
\text { Moderate cytoplasm, } \\
\text { indistinct borders. Nuclei } \\
\text { were ovoid, prominent } \\
\text { nucleoli with slight } \\
\text { pleomorphism. } 11 \\
\text { mitoses per hpf }\end{array}$ & $\begin{array}{l}\text { Wide excision, } \\
\text { transposition flap }\end{array}$ \\
\hline $\begin{array}{l}\text { 4) McMichael } \\
\text { et al. } .^{5}\end{array}$ & $\begin{array}{l}\text { Female, } \\
\text { African } \\
\text { American }\end{array}$ & 71 & Left ear & $\begin{array}{l}2.0 \mathrm{~cm} \times 1.7 \mathrm{~cm} \text { irregularly } \\
\text { shaped nodule on antihelix of } \\
\text { the left ear; smooth multilobed } \\
\text { and deep purple in color, } \\
\text { hyperpigmentation in multiple } \\
\text { areas. Sites of excoriation, no } \\
\text { bleeding or purulence }\end{array}$ & $>20$ years & $\begin{array}{l}\text { No cervical } \\
\text { lymphadenopathy }\end{array}$ & $\begin{array}{l}\text { Poorly circumscribed } \\
\text { neoplasm involving } \\
\text { epidermis and extending } \\
\text { to the base of biopsy. } \\
\text { Anastomosing bands } \\
\text { and sheets of squamous } \\
\text { and basaloid cells } \\
\text { focally exhibiting } \\
\text { ductular differentiation, } \\
\text { including the formation } \\
\text { of cuticles. Moderate } \\
\text { pleomorphism. }\end{array}$ & $\begin{array}{l}\text { Mohs surgery total } \\
\text { removal of lesion done } \\
\text { in } 1 \text { stage }\end{array}$ \\
\hline 5) Goel et al. ${ }^{6}$ & $\begin{array}{l}\text { Male, } \\
\text { African } \\
\text { American }\end{array}$ & 42 & $\begin{array}{l}\text { Plantar } \\
\text { surface of } \\
\text { right foot }\end{array}$ & $\mathrm{n} / \mathrm{a}$ & $>2$ years & $\begin{array}{l}\text { Diffuse } \\
\text { anterior/posterior } \\
\text { cervical } \\
\text { lymphadenopathy, right } \\
\text { axillary mass, bilateral } \\
\text { inguinal } \\
\text { lymphadenopathy }\end{array}$ & $\begin{array}{l}\text { Basaloid cells with } \\
\text { eosinophilic cytoplasm } \\
\text { beneath an ulcerated } \\
\text { surface. Diffuse areas of } \\
\text { necrosis, individual cell } \\
\text { necrosis, and numerous } \\
\text { mitotic figures. Ductular } \\
\text { structures lined by an } \\
\text { eosinophilic, basement } \\
\text { membrane like material. } \\
\text { Ducts were highlighted } \\
\text { by a polyclonal CEA. }\end{array}$ & $\begin{array}{l}\text { Passed away } 2 \text { years } \\
\text { after initial diagnosis } \\
\text { secondary to } \\
\text { widespread eccrine } \\
\text { porocarcinoma }\end{array}$ \\
\hline $\begin{array}{l}\text { 6) } \\
\text { Ramasendaran } \\
\text { et al. }{ }^{7}\end{array}$ & $\begin{array}{l}\text { Female, } \\
\text { Asian }\end{array}$ & 65 & Left forearm & $\begin{array}{l}\text { Hard-pedunculated mass over } \\
\text { the anteromedial aspect of } \\
\text { the left mid-forearm } \\
\text { measuring } 6 \times 5 \mathrm{~cm} \text {, } \\
\text { erythematous, cauliflower-like } \\
\text { growth with a stalk measuring } \\
\text { approximately } 1 \mathrm{~cm} \text {, and } \\
\text { visible feeding vessels. } \\
\text { Referred for melanoma. }\end{array}$ & $>5$ years & $\begin{array}{l}\text { No lymphadenopathy, } \\
\text { no nodal involvement or } \\
\text { distant metastasis }\end{array}$ & $\begin{array}{l}\text { Inconspicuous } \\
\text { intercellular bridges } \\
\text { extending into the } \\
\text { dermis. Atypical cells } \\
\text { include eosinophilic } \\
\text { cells, pigmented cells } \\
\text { with focal squamous } \\
\text { differentiation, and } \\
\text { ductal-like structures. } \\
\text { Nuclear atypia with } \\
\text { frequent mitoses and } \\
\text { focal necrosis. Stroma } \\
\text { shows proliferation of } \\
\text { reactive vessels and } \\
\text { mild chronic } \\
\text { inflammation. Tumor } \\
\text { cells immunoreactive to } \\
\text { CK } 7 \text { and non-reactive } \\
\text { to S100. Tumor depth } \\
>35 m m \text {, increased } \\
\text { mitotic activity. "High risk } \\
\text { histology type." }\end{array}$ & $\begin{array}{l}\text { Excision of left forearm } \\
\text { lesion under general } \\
\text { anesthesia }\end{array}$ \\
\hline $\begin{array}{l}\text { 7) Godinez- } \\
\text { Puig et al. }\end{array}$ & $\begin{array}{l}\text { Female, } \\
\text { Hispanic }\end{array}$ & 80 & Left thigh & $\begin{array}{l}2.2 \times 1.7 \mathrm{~cm} \text { sessile, smooth, } \\
\text { deep purple, nodule on the } \\
\text { left lateral posterior thigh. } \\
\text { Dermoscopic exam revealed } \\
\text { exophytic nodule with } \\
\text { greenish blue pigmented }\end{array}$ & $\begin{array}{l}>10 \text { years, } \\
\text { more } \\
\text { aggressive } \\
\text { growth over } \\
\text { past } 3 \\
\text { months }\end{array}$ & No lymphadenopathy & $\begin{array}{l}\text { Dermal infiltrative nodule } \\
\text { with large, } \\
\text { interconnected lobules } \\
\text { and strands of large } \\
\text { polygonal cells with focal } \\
\text { ductal differentiation. }\end{array}$ & $\begin{array}{l}\text { Mohs micrographic } \\
\text { surgery tumor negative } \\
\text { margins achieved after } \\
2 \text { stages }\end{array}$ \\
\hline
\end{tabular}




\begin{tabular}{|c|c|c|c|c|c|c|c|c|}
\hline & & & & $\begin{array}{l}\text { globules interspersed by } \\
\text { prominent irregular arborizing } \\
\text { vessels resembling a } \\
\text { pigmented BCC. }\end{array}$ & & & $\begin{array}{l}\text { Zones of tumor necrosis } \\
\text { were also identified. } \\
\text { Nuclear atypia and } \\
\text { frequent mitotic activity }\end{array}$ & \\
\hline $\begin{array}{l}\text { 8) Vleugels et } \\
\text { al. }{ }^{9}\end{array}$ & $\begin{array}{l}\text { Female, } \\
\text { Hispanic }\end{array}$ & 59 & $\begin{array}{l}\text { Left ventral } \\
\text { forearm }\end{array}$ & $\begin{array}{l}2.5-\mathrm{cm} \text { pink to violaceous } \\
\text { pedunculated nodule with } \\
\text { hemorrhagic crusting on a } \\
1.5-\mathrm{cm} \text { base }\end{array}$ & 3 years & $\begin{array}{l}\text { No lymphadenopathy } \\
\text { but } 2 \text { years later tumor } \\
\text { reappeared in left axilla }\end{array}$ & $\begin{array}{l}\text { Small cuboidal cells } \\
\text { forming duct-like lumina } \\
\text { that extended into the } \\
\text { reticular dermis. 10mm } \\
\text { tumor depth, lobular } \\
\text { infiltrative growth, } \\
\text { numerous mitoses. } \\
\text { Comedonecrosis, } \\
\text { nuclear and cytoplasmic } \\
\text { pleomorphism, and } \\
\text { atypical mitotic figures. }\end{array}$ & $\begin{array}{l}\text { Negative margin Mohs } \\
\text { micrographic surgery, } \\
\text { radical left axillary } \\
\text { lymphadenectomy }\end{array}$ \\
\hline $\begin{array}{l}\text { 9) Nakanishi et } \\
\text { al. }^{10}\end{array}$ & $\begin{array}{l}\text { Male, } \\
\text { Japanese }\end{array}$ & 74 & Leg & $\begin{array}{l}\text { Brown-black nodule } \\
\text { measuring } 9 \times 7 \mathrm{~mm} \text { is } \\
\text { surrounded by a slightly } \\
\text { elevated whitish halo }\end{array}$ & $n / a$ & $n / a$ & $\begin{array}{l}\text { Irregular nests of } \\
\text { atypical cells extended } \\
\text { into the dermis. Poroid } \\
\text { tumor cells were PAS } \\
\text { positive. Dendritic } \\
\text { melanocytes containing } \\
\text { melanin are intermingled } \\
\text { with the tumor cells. } \\
\text { Eosinophilic globules } \\
\text { are evident within some } \\
\text { tumor cells. Dendritic } \\
\text { cells containing } \\
\text { melanin positive for } \\
\text { HMB-45 and S-100. } \\
\text { Tumor cells: Negative } \\
\text { for CEA, HMB-45, S- } \\
100 . \text { Positive for AE1- } \\
\text { AE3, KL-1. }\end{array}$ & $\begin{array}{l}10 \text { months follow up } \\
\text { showed no recurrence } \\
\text { or metastasis of tumor }\end{array}$ \\
\hline $\begin{array}{l}\text { 10) K.Hara, } \\
\text { S.Kamiya }\end{array}$ & $\begin{array}{l}\text { Female, } \\
\text { Japanese }\end{array}$ & 77 & Back & $\begin{array}{l}10 \times 12 \mathrm{~mm} \text {, surrounded by } \\
\text { papules forming an } \\
\text { incomplete ring measuring } 22 \\
\times 18 \mathrm{~mm}\end{array}$ & $\mathrm{n} / \mathrm{a}$ & $\begin{array}{l}\text { Small axillary lymph } \\
\text { nodes were palpable }\end{array}$ & $\begin{array}{l}\text { Irregular nests of } \\
\text { atypical cells in the } \\
\text { acanthotic epidermis } \\
\text { with extension into deep } \\
\text { dermis. In nests, } \\
\text { aggregates of small } \\
\text { basaloid cells and larger } \\
\text { cells with abundant } \\
\text { eosinophilic cytoplasm. } \\
\text { Dendritic melanocytes } \\
\text { containing melanin were } \\
\text { intermingled with the } \\
\text { tumor cells. }\end{array}$ & $\begin{array}{l}\text { Wide local excision, } \\
17 \text { mos later patient } \\
\text { died of pneumonia with } \\
\text { no evidence of residual } \\
\text { tumor }\end{array}$ \\
\hline $\begin{array}{l}\text { 11) Masamati } \\
\text { et al. }{ }^{11}\end{array}$ & $\begin{array}{l}\text { Female, } \\
\text { Indian }\end{array}$ & 29 & $\begin{array}{l}\text { Parieto } \\
\text { occipital } \\
\text { scalp }\end{array}$ & $\begin{array}{l}6 \times 5 \times 3 \mathrm{~cm} \text {, showing surface } \\
\text { ulceration with focal loss of } \\
\text { hair and along with loss of } \\
\text { pigmentation. Mobile mass, } \\
\text { free from underlying } \\
\text { structures and bled on touch } \\
\text { Misdiagnosis as soft tissue } \\
\text { sarcoma }\end{array}$ & 1 year & None & $\begin{array}{l}\text { Infiltrating tumor with } \\
\text { polygonal to cuboidal } \\
\text { cells having pleomorphic } \\
\text { vesicular nuclei. } \\
\text { Prominent one to two } \\
\text { nucleoli, moderate to } \\
\text { abundant pale } \\
\text { cytoplasm arranged in } \\
\text { lobules, nests and } \\
\text { cords. Separated by } \\
\text { thick fibrous septae. } \\
\text { Tumor depth of } 8 \mathrm{~mm} \\
\text { with infiltrating borders, } \\
\text { mitotic rate }>14 / 10 \text { hpf, } \\
\text { few lymphatic tumor } \\
\text { emboli and foci of tumor } \\
\text { necrosis indicating poor } \\
\text { prognosis. + for CEA, } \\
\text { PAS stain }\end{array}$ & $\begin{array}{l}\text { Local excision with } \\
\text { negative margins, } \\
\text { Recurrence after } 6 \text { mos } \\
\text { of surgery }\end{array}$ \\
\hline $\begin{array}{l}\text { 12) Maeda et } \\
\text { al. }{ }^{12}\end{array}$ & $\begin{array}{l}\text { Male, } \\
\text { Japanese }\end{array}$ & 58 & Left waist & $\begin{array}{l}\text { Flat, dark tumor of } \\
1 \mathrm{~cm} \text { in diameter developed } \\
\text { on a pre-existing pigmented } \\
\text { spot } \\
\text { Misdiagnosis of malignant } \\
\text { melanoma. }\end{array}$ & $>30$ years & $\begin{array}{l}\text { Left lower leg reached } \\
\text { the inguinal region. } \\
\text { Scrotal swelling. Left } \\
\text { supraclavicular lymph } \\
\text { node enlargement. }\end{array}$ & $\begin{array}{l}\text { Intraepidermal nests } \\
\text { contained more dendritic } \\
\text { melanocytes } \\
\text { than in the adjacent } \\
\text { epidermis }\end{array}$ & Not specified \\
\hline $\begin{array}{l}\text { 13) Current } \\
\text { Case }\end{array}$ & $\begin{array}{l}\text { Male, } \\
\text { African } \\
\text { American }\end{array}$ & 82 & $\begin{array}{l}\text { Right lateral } \\
\text { malleolus }\end{array}$ & $\begin{array}{l}2 \times 1.5 \mathrm{~cm} \text { skin colored } \\
\text { nodule with an erosive center }\end{array}$ & $>3$ years & $\begin{array}{l}\text { Inguinal } \\
\text { lymphadenopathy }\end{array}$ & $\begin{array}{l}\text { Exophytic lesion of skin } \\
\text { proliferation of atypical } \\
\text { epithelial cells } \\
\text { emanating from the } \\
\text { epidermis into the } \\
\text { dermis. Small duct-like } \\
\text { structures within and } \\
\text { resembled } \\
\text { anastomosing wide } \\
\text { bands of cells. Epithelial } \\
\text { cells with enlarged, } \\
\text { hyperchromatic, and } \\
\text { pleomorphic nuclei } \\
\text { surrounded by } \\
\text { eosinophilic cytoplasm. } \\
\text { Atypical mitoses } \\
\text { present, neoplasm } \\
\text { surrounded by a } \\
\text { prominent fibrovascular } \\
\text { stroma. }\end{array}$ & Mohs surgery \\
\hline
\end{tabular}


males $(n=5)$, consistent with findings by Robson et. al. The age in patients of color (range: 29-82, average: 61.84, median: 65 years) was slightly younger than the average and median age reported by Robson et.al (range: 29-91, mean: 73, median: 78), but in line with observations that EPC affects the elderly in their sixth or seventh decade of life. In patients of color, the tumor showed variable appearance, as a sessile or pedunculated mass, verrucous plaques, nodules, and some with bleeding and ulcerations. The most common site of EPC in patients of color was the lower extremity ( 50\%), but also appeared on the head, neck, and upper extremity, consistent with the literature. A long period of clinical history is the norm for EPCs, ranging from 2 weeks to 60 years. The average preoperative duration of reported lesion growth in patients of color was similar to that reported by Robson et. al, with 8.81 years vs. 9 respectively. Most of the histopathology findings showed eccrine ductal differentiation, but malignant squamous cells, melanocytes, and clear cells were also present in many cases. 3 out of the 13 cases of EPC in skin of color were classified as "pigmented EPC", coined by Hara and Kamiya in 1995 to describe histology showing melanocyte symbiosis with tumor cells. Dendritic cells containing melanin stained positive for HMB-45 and S100 whereas ductal tumor cells were reactive to markers such as CEA, CK-7 and non-reactive to S-100. Approximately 33\% $(n=4)$ patients of color had lymph node involvement, $>7 \mathrm{~mm}$ depth of tumor invasion, and $>14$ mitoses per high power field, which are associated with poor prognosis in patients with EPC. This is higher than the $20 \%$ lymph node metastasis for EPC cases that Robson et. al report in their review.

\section{DISCUSSION}

The review of a small number of cases seem to suggest a more advanced EPC tumor presentation in patients of color than lighter skinned patients. This trend is similar to findings in melanoma which showed that Hispanic (26\%) and Black patients (52\%) had more advanced melanoma at presentation compared with Caucasian patients $(16 \%){ }^{2}$ The $33 \%$ lymph node metastasis observed in patients of color with EPC is higher than the rates of metastatic BCC in all races: 0.0028 to $0.55 \%$, but similar to rates of metastatic SCC that develops within a chronic scarring process more seen in skin of color: $20-40 \%{ }^{2}$

\section{CONCLUSION}

Clinicians should also be aware of atypical clinical and histological variants of EPC in people of color such as pigmented EPC, which can be confused for malignant melanoma. Misdiagnosis of EPC can have significant consequences given that the cancer has the potential to be aggressive. It is thought that $20 \%$ of EPC recur locally, an additional $20 \%$ metastasize, and mortality rates of $67 \%$ are seen when local lymph nodes are involved. ${ }^{3}$ Therefore, the differential diagnoses of these lesions must be considered and ruled out using thorough dermatopathological analysis. Additional case details and a larger sample size are needed before determining diagnostic and treatment guidelines, mortality, and risk associated with EPC in skin of color.

Conflict of Interest Disclosures: None

Funding: None

(c) 2022 THE AUTHORS. Published by the National Society for Cutaneous Medicine. 
Corresponding Author:

Maral Kibarian Skelsey MD

5530 Wisconsin Ave \# 820

Chevy Chase, MD 20815

Email: Dr.Maral.Skelsey@mohs-md.com

\section{References:}

1. Robson A, Greene J, Ansari N, et al. Eccrine porocarcinoma (malignant eccrine poroma): A clinicopathologic study of 69 cases. The American journal of surgical pathology. 2001;25(6):710-720.

https://www.ncbi.nlm.nih.gov/pubmed/11395548. doi: 10.1097/00000478-200106000-00002.

2. Gloster HM, Neal K. Skin cancer in skin of color. Journal of the American Academy of Dermatology. 2006;55(5):741-760. https://dx.doi.org/10.1016/j.jaad.2005.08.063. doi: 10.1016/j.jaad.2005.08.063.

3. Cowden A, Dans M, Militello G, Junkins-Hopkins $\mathrm{J}$, Voorhees AS. Eccrine porocarcinoma arising in two African American patients: Distinct presentations both treated with mohs micrographic surgery. International Journal of Dermatology. 2006;45(2):146-150. https://onlinelibrary.wiley.com/doi/abs/10.1111/j.1 365-4632.2006.02735.x. doi: 10.1111/j.13654632.2006.02735.x.

4. Girishkumar H, Kamineni S, Hwang RR, Levy J, Sadler R. Eccrine porocarcinoma. Dermatol Surg. 1997;23(7):583-584. doi:10.1111/j.15244725.1997.tb00692.x

5. McMichael AJ, Gay J. Malignant eccrine poroma in an elderly African-American woman. Dermatologic Surgery. 1999;25(9):733-735. https://onlinelibrary.wiley.com/doi/abs/10.1046/j.1 524-4725.1999.99041.x. doi: 10.1046/j.15244725.1999.99041.x.

6. Goel R, Contos MJ, Wallace ML. Widespread metastatic eccrine porocarcinoma. Journal of the American Academy of Dermatology.

2003;49(5):252-254. http://dx.doi.org/10.1016/S0190-9622(03)004444. doi: 10.1016/S0190-9622(03)00444-4.

7. Ramasenderan N, Shahir H, Omar SZ. A synchronous incidence of eccrine porocarcinoma of the forearm and facial squamous cell carcinoma: A case report. International journal of surgery case reports. 2017;42:116-120. https://www.ncbi.nlm.nih.gov/pubmed/29245095. doi: 10.1016/j.jijscr.2017.11.066.

8. Godinez-Puig V, Martini M, Yazdan P, Yoo S. Dermoscopic findings in porocarcinoma.
Dermatologic surgery. 2016;43(5):744-745. https://www.ncbi.nlm.nih.gov/pubmed/28005624. doi: 10.1097/DSS.0000000000001010.

9. Vleugels FR, Girouard SD, Schmults CD, et al. Metastatic eccrine porocarcinoma after mohs micrographic surgery: A case report. Journal of clinical oncology. 2012;30(21):e188-e191. https://www.ncbi.nlm.nih.gov/pubmed/22689795. doi: 10.1200/JCO.2011.40.6843.

10. Nakanishi, Matsuno, Shimoda, et al. Eccrine porocarcinoma with melanocyte colonization. British journal of dermatology (1951). 1998;138(3):519-521. http://www.ingentaconnect.com/content/bsc/bjd/1 998/00000138/00000003/art00026. doi: 10.1046/j.1365-2133.1998.02137.x.

11. Masamatti SS, Narasimha A, Bhat A, Chowdappa V. Eccrine porocarcinoma of the scalp: A rare case report with review of literature. Journal of clinical and diagnostic research. 2016;10(1):ED15-ED16. https://www.ncbi.nlm.nih.gov/pubmed/26894080. doi: 10.7860/JCDR/2016/16083.7149.

12. Maeda $T$, Mori $H$, Matsuo $T$, et al. Malignant eccrine poroma with multiple visceral metastases: Report of a case with autopsy findings. Journal of cutaneous pathology. 1996;23(6):566-570. https://onlinelibrary.wiley.com/doi/abs/10.1111/j.1 600-0560.1996.tb01451.x. doi: 10.1111/j.16000560.1996.tb01451.x. 3. 